\title{
The Effect of Tax Planning on Financial Performance in the Stock Exchange of Thailand
}

\author{
Sathaya Thanjunpong and Thatphong Awirothananon
}

\begin{abstract}
This paper aims to examine the association of tax planning (hereafter called TP) on financial performance (hereafter called FP) in the Stock Exchange of Thailand during the year 2014-2016. The sample size, which excludes the financial sector, consists of 873 firm-years. The TP is measured by effective tax rate (hereafter called ETR) and the ratio of tax expenses to total assets (hereafter called TAX/ASSET), while the FP is measured by return on equity. This paper finds that the TP has both effects on the FP. The effect is positive when measured by ETR, while it is negative if measurement is TAX/ASSET. Regarding to control variables, the BIG4 auditors have positive effects on the FP. The results further indicate that the relationship between the FP and TP (measured by TAX/ASSET) is significantly negative for non-BIG4 auditors. The relationship is thus weak and insignificant for BIG4 auditors. The results are, therefore, useful to provide guideline for listed companies in managing capital and resources more efficiently.
\end{abstract}

Index Terms-Effective tax rate, financial performance, listed companies, tax planning.

\section{INTRODUCTION}

The tax planning (hereafter called TP) is where along the continuum depending upon how aggressive companies' activities are in reducing corporate income tax. The tax avoidance (hereafter called TA) is also within the legal framework of the tax law. It consists in exploiting loopholes in the tax law in order to reduce companies' tax liabilities or anything that reduces companies' cash effective tax rate over a long time period [1]. Taxes represent significant costs to companies and shareholders; therefore, the TA is a part of TP. It is generally expected that shareholders prefer the TP. Many companies are generally looking for means to reduce their corporate income tax [2]. Accordingly, the corporate TP represents wealth transfer from the government to corporates and should increase their financial performance (hereafter called FP).

Empirical researches on the effect of TP on the FP are mixed. Many previous papers, including References [3]-[8], show that the TP has a positively significant impact on the increasing of FP. Reference [4], for example, show that the TP has a significantly positive relationship on the FP in listed companies in Indonesia. Moreover, board diversities (e.g., age, education, and background of member director in economics and business aspects) could increase a positive influence of TP into the FP. Reference [7] also finds that the

Manuscript received October 9, 2018; revised January 25, 2019.

The authors are with Faculty of Business Administration, Maejo University, Sansai, Chiang Mai 50290, Thailand (Corresponding author: Thatphong Awirothananon; e-mail: sathayat@gmail.com). relationship between TA and firm value (measured by Tobin's Q [9]) is positively significant, especially in developed and common law countries. However, some prior papers, including References [10]-[15], show that the TA has a negatively significant impact on the FP. Reference [11], for instance, reveals that the TA has a negatively significant effect on companies' value in China. Reference [12] further shows that the TA and companies' value are negatively related in Brazil. Reference [14] also shows that the corporate TA has a significantly negative direct relationship on market value of companies. Reference [8] finds that the top-ten shareholders are positively and significantly associated with the corporate TP. Nevertheless, Reference [16] shows that the TP has no significant effect on the FP in Nigeria. Reference [17] further shows that the TA does not have a significant effect on the FP in the US; however, the interaction between TA and corporate governance has a positive effect on the FP.

In Thailand, BIG4 auditors are employed by listed companies since they could produce higher auditing quality than non-Big4 auditors do [18]. In addition, auditors play an important role in the areas of internal control and financial reporting of companies. Several empirical papers, including References [19]-[23], focus on the relationship between auditing quality and the FP. References [19], [20], for example, suggest that BIG4 auditors are expected to have more incentives to preserve their independence and provide high-quality auditing services to maintain their reputation and enlarge their portfolio. Reference [21] further investigates the effect of auditing quality and financial statement quality for 32 listed companies in Taiwan for the period of 1996-2009. Auditing quality is also measured by the auditor size (BIG4 versus non-BIG4 auditors). The results show that the earnings and book value of equity, which are audited by BIG4 auditors, could explain more variations in the stock return of companies than non-BIG4 auditors do. Reference [22] also reveals that market participants highly value BIG4 auditors with industrial experience. BIG4 auditors are, therefore, associated with higher companies' value. Reference [23] further finds that the auditing quality positively and significantly affects the value relevance of accounting measures to market participants. Many previous results also show that auditor type is positively associated with the FP. On the other hand, some prior studies report that BIG4 auditors are not associated with the FP. Reference [24], for example, investigates the effect of auditing quality on the FP for Malaysian listed companies for the period of 2003-2012. The results show that auditing quality has an insignificant effect on the FP. This paper, therefore, aims to search the benefit of TA and audit quality implementations to the FP in Thai listed companies. 


\section{ReSEARCH Methodology}

The population of this paper are listed companies, which are excluded financial sectors (around 58 companies), in the Stock Exchange of Thailand (hereafter called SET) during the years 2014-2016. The sample selection technique is the purposive sampling method, where the sample is chosen in accordance with companies those publish their information (such as financial statements, annual report, and Form 56-1) on their website, and SETSMART database with completed year period of 2014-2016. Based on the above criteria, there are only 873 firm-years those could be a sample for this paper. These companies are in seven industries according to the SET categorisation, which are (1) agro and food industry 103 firm-years, (2) consumer products 76 firm-years, (3) industrials 160 firm-years, (4) property and construction 189 firm-years, (5) resources 72 firm-years, (6) services 195 firm-years, and (7) technology 78 firm-years, respectively.

For the purpose of this paper, the TP is defined as the ability to reduce tax expenses by reducing taxable income without reducing book income, as popular measured by effective tax rate (hereafter called ETR), while a new measurement is purposed by Reference [25], which is measured by the ratio of tax expenses to total assets (hereafter called TAX/ASSET). The dependent variable of this paper is the FP, measured by the natural logarithm of return on equity (hereafter called ROE), which is calculated as the net income for the year divided by the total equity. This paper also includes some control variables that have been shown to have a significant impact on the FP (see References [26]-[30]). Following References [28], [29], this paper uses firm size (hereafter called SIZE) as one of the main control variables measured by the natural logarithm of total assets. Financial leverage (hereafter called LEV) is also calculated as the percentage of total debt to total assets for the differences in the financial structure of companies. This paper includes the return on assets (hereafter called ROA) by dividing the net income to total assets as an indicator of FP. In addition, this paper uses capital intensity (hereafter called CAP) by dividing the property, plant, and equipment to total assets as an indicator of companies' working capital management. Moreover, this paper uses BIG4 auditors (such as Deloitte, Pwc, Ernst \& Young, and KPMG) as a proxy for auditors' reputation, and assigns a value of one when companies employ BIG4 auditors and zero otherwise. The last variable is an industrial index (hereafter called IND), which is a dummy variable, according to the SET categorisation.

This paper uses multiple regression analysis technique to determine the relationship between TP and FP. Based on the purpose of this paper, there will be a regression on full sample model as follows:

$$
\begin{gathered}
\mathrm{FP}_{\mathrm{it}}=\beta_{0}+\beta_{1} \mathrm{TP}_{\mathrm{it}}+\beta_{2} \mathrm{SIZE}_{\mathrm{it}}+\beta_{3} \mathrm{LEV}_{\mathrm{it}}+\beta_{4} \mathrm{ROA}_{\mathrm{it}}+\beta_{5} \mathrm{CAP}_{\mathrm{it}}+ \\
\beta_{6} \mathrm{BIG}_{\mathrm{it}}+\sum_{k=7}^{12} \beta_{k} \mathrm{IND}_{k}+\sum_{k=13}^{14} \beta_{k} \mathrm{YEAR}_{k}
\end{gathered}
$$

Additionally, this paper divides the full sample model into two sub-groups (BIG4 and non-BIG4 auditors) to examine whether there are any differences in TP on the FP among BIG4 and non-BIG4 auditors (Models 2.1 and 2.2).

$$
\begin{aligned}
\mathrm{FP}_{\mathrm{it}}=\beta_{0}+ & \beta_{1} \mathrm{TP}_{\mathrm{it}}+\beta_{2} \mathrm{SIZE}_{\mathrm{it}}+\beta_{3} \mathrm{LEV}_{\mathrm{it}}+\beta_{4} \mathrm{ROA}_{\mathrm{it}}+\beta_{5} \mathrm{CAP}_{\mathrm{it}} \\
& +\sum_{k=6}^{11} \beta_{k} \mathrm{IND}_{k}+\sum_{k=12}^{13} \beta_{k} \mathrm{YEAR}_{k}
\end{aligned}
$$

\section{RESULTS AND DISCUSSION}

TABLE I presents descriptive statistics for the full and two sub-samples (BIG4 and non-BIG4 auditors). It also reports the mean value of all variables and the $t$-statistics of mean differences between BIG4 and non-BIG4 auditors. It shows a mean value of ETR for the full sample of 0.168 , while the mean for BIG4 and non-BIG4 auditors are 0.162 and 0.177 , respectively. It also presents that the ETR value is not statistically significant differences between BIG4 and

\begin{tabular}{|c|c|c|c|c|c|c|c|}
\hline \multirow[b]{2}{*}{ Variables } & \multicolumn{2}{|c|}{$\begin{array}{c}\text { Full sample } \\
(n=866)\end{array}$} & \multicolumn{2}{|c|}{$\begin{array}{c}\text { BIG4 } \\
(n=554)\end{array}$} & \multicolumn{2}{|c|}{$\begin{array}{c}\text { Non-BIG4 } \\
(n=312)\end{array}$} & \multirow{2}{*}{$\begin{array}{c}t \text {-statistics of mean } \\
\text { difference }\end{array}$} \\
\hline & Mean & SD & Mean & $\mathrm{SD}$ & Mean & $\mathrm{SD}$ & \\
\hline ROE & -2.389 & 1.047 & -2.283 & 0.985 & -2.578 & 1.127 & $3.872 * *$ \\
\hline ETR & 0.168 & 0.145 & 0.162 & 0.128 & 0.177 & 0.171 & 1.398 \\
\hline TAX/ASSET & 0.014 & 0.015 & 0.014 & 0.014 & 0.014 & 0.154 & 0.671 \\
\hline SIZE & 22.654 & 1.469 & 23.035 & 1.494 & 21.977 & 1.145 & $11.667 * *$ \\
\hline ROA & 0.096 & 0.079 & 0.097 & 0.064 & 0.096 & 0.100 & 0.099 \\
\hline CAP & 0.334 & 0.289 & 0.335 & 0.314 & 0.332 & 0.236 & 0.131 \\
\hline BIG4 & 0.640 & 0.480 & & & & & \\
\hline
\end{tabular}
non-BIG4 auditors. The ETR value of BIG4 auditors is, therefore, the same as that of non-BIG4 auditors.

TABLE I: DESCRIPTIVE STATISTICS

Notes: ROE is the natural logarithm of the percentage of net income to equity; ETR is the tax expenses for the year divided by earnings before taxes; TAX/ASSET is tax expenses for the year divided by the total assets; SIZE is the natural logarithm of total assets; LEV is the percentage of total debt to total assets; ROA is the percentage of the earnings before taxes to total assets; CAP is the percentage of the net property, plant, and equipment to total assets; BIG4 has the value of one when the firm has BIG4 auditors and zero otherwise; One and two asterisks indicate statistical significance at the 0.05 level and 0.01 level, respectively.

The descriptive statistics in TABLE I show that the average value of TAX/ASSET for the full sample, the means for BIG4 and non-BIG4 auditors are 0.014 . In addition, the t-statistics for the mean differences of TP between BIG4 and non-BIG4 auditors is not statistical significance. The results also show that BIG4 auditors have better TP than non-BIG4 auditors do because either ETR or TAX/ASSET is low, resulting that the level of TP is higher. Additionally, the mean value of SIZE for 
the full sample is 22.654, while the means for BIG4 and non-BIG4 auditors are 23.035 and 21.977, respectively. The results for the $t$-statistics of the mean differences between BIG4 and non-BIG4 auditors are statistically significant at the 0.05 level, which indicates that SIZE for BIG4 auditors is greater than in non-BIG4 auditors. Moreover, the average value of LEV for the full sample is 0.417 , while the means for BIG4 and non-BIG4 auditors are 0.447 and 0.362 , respectively. However, the average value of ROA for the full sample is 0.096, while the means for BIG4 and non-BIG4 auditors are 0.097 and 0.096 , respectively. Furthermore, the mean value of CAP for the full sample is 0.334 , while the means for BIG4 and non-BIG4 auditors are 0.335 and 0.332 , respectively. Furthermore, the mean value of BIG4 for the full sample is 0.640 . This indicates that most companies prefer high quality audit services.

Pearson product-moment correlation, as shown in Table II, is computed to examine the correlation of all variables. The correlation value between ROE and TP (measured by ETR), for example, is 0.243 , which is statistically and negatively significant at the 0.05 level. The ROE, however, has a statistically negative relationship (the value of -0.489) with the TP (measured by TAX/ASSET) at the 0.05 level. The correlations between explanatory variables also are between 0.001 and 0.686 . These values are relatively low, which are below \pm 0.700 , indicating that the multicollinearity problem is not exist during the multiple regression analysis [31]. For instance, the correlation value between SIZE and LEV is 0.447 , which is statistically significant at the 0.05 level. This paper further considers whether the data has a normal distribution or not. According to Reference [32] statement, the sampling distribution become almost normal, regardless of the shape of population since the sample size is large enough, which is normally greater than 30 observations. The data of this paper, therefore, has a normal distribution.

TABLE II: PEARSON CORRELATION MATRIX

\begin{tabular}{|c|c|c|c|c|c|c|c|c|}
\hline & ROE & ETR & TAX/ASSET & SIZE & LEV & ROA & CAP & BIG4 \\
\hline $\mathrm{ROE}$ & 1.000 & & & & & & & \\
\hline ETR & $0.243^{* *}$ & 1.000 & & & & & & \\
\hline TAX/ASSET & $-0.489 * *$ & $-0.190 * *$ & 1.000 & & & & & \\
\hline SIZE & $0.082 *$ & 0.005 & $0.092 * *$ & 1.000 & & & & \\
\hline LEV & $0.096^{* *}$ & $-0.093 * *$ & $0.156^{* *}$ & $0.447^{* *} *$ & 1.000 & & & \\
\hline ROA & $0.615^{* *}$ & $0.103 * *$ & $-0.686^{* *}$ & $-0.077^{*}$ & $-0.180 * *$ & 1.000 & & \\
\hline CAP & -0.033 & 0.045 & 0.022 & -0.058 & $-0.087^{*}$ & 0.004 & 1.000 & \\
\hline BIG4 & $0.136^{* *}$ & $0.079 *$ & 0.020 & $0.349 * *$ & $0.202 * *$ & 0.009 & 0.001 & 1.000 \\
\hline
\end{tabular}

Notes: ROE is the natural logarithm of the percentage of net income to equity; ETR is the tax expenses for the year divided by earnings before taxes TAX/ASSET is tax expenses for the year divided by the total assets; SIZE is the natural logarithm of total assets; LEV is the percentage of total debt to total assets; ROA is the percentage of the earnings before taxes to total assets; CAP is the percentage of the net property, plant, and equipment to total assets; BIG4 has the value of one when the firm has BIG4 auditors and zero otherwise; One and two asterisks indicate statistical significance at the 0.05 level and 0.01 level, respectively.

TABLE III: EFFECTS OF TAX PLANNING AND AUdITORS’ REPUTATION ON FINANCIAL PERFORMANCE

\begin{tabular}{|c|c|c|c|c|c|c|c|c|c|c|c|c|}
\hline \multirow{2}{*}{$\begin{array}{c}\text { Dependent } \\
\text { variable: ROE } \\
\text { Independent } \\
\text { variables: }\end{array}$} & \multicolumn{2}{|c|}{$\begin{array}{l}\text { Full sample } \\
\quad(n=866)\end{array}$} & \multicolumn{2}{|c|}{$\begin{array}{c}\text { BIG4 } \\
(n=554)\end{array}$} & \multicolumn{2}{|c|}{$\begin{array}{l}\text { Non-BIG4 } \\
(n=312)\end{array}$} & \multicolumn{2}{|c|}{$\begin{array}{l}\text { Full sample } \\
\quad(n=866)\end{array}$} & \multicolumn{2}{|c|}{$\begin{array}{c}\text { BIG4 } \\
(n=554)\end{array}$} & \multicolumn{2}{|c|}{$\begin{array}{l}\text { Non-BIG4 } \\
(n=312)\end{array}$} \\
\hline & $\beta$ & VIF & $\beta$ & VIF & $\beta$ & VIF & $\beta$ & VIF & $\beta$ & VIF & $\beta$ & VIF \\
\hline Intercept & $\begin{array}{l}-3.367 * * \\
(0.484)\end{array}$ & & $\begin{array}{l}-3.489 * * \\
(0.477)\end{array}$ & & $\begin{array}{l}-3.096 * * \\
(1.182)\end{array}$ & & $\begin{array}{l}-3.987 * * \\
(0.499)\end{array}$ & & $\begin{array}{l}-3.873 * * \\
(0.504)\end{array}$ & & $\begin{array}{l}-4.279 * * \\
(1.162)\end{array}$ & \\
\hline TP & $\begin{array}{l}1.632 * * \\
(0.182)\end{array}$ & 1.060 & $\begin{array}{l}1.762 * * \\
(0.214)\end{array}$ & 1.068 & $\begin{array}{l}1.445^{* *} \\
(0.306)\end{array}$ & 1.072 & $\begin{array}{l}-10.554 * * \\
(2.527)\end{array}$ & 1.931 & $\begin{array}{c}3.641 \\
(2.786)\end{array}$ & 1.978 & $\begin{array}{c}-25.487 * * \\
(4.675)\end{array}$ & 2.054 \\
\hline SIZE & $\begin{array}{c}0.001 \\
(0.020)\end{array}$ & 1.548 & $\begin{array}{l}-0.008 \\
(0.021)\end{array}$ & 1.333 & $\begin{array}{l}-0.003 \\
(0.055)\end{array}$ & 1.525 & $\begin{array}{c}0.015 \\
(0.022)\end{array}$ & 1.548 & $\begin{array}{l}-0.005 \\
(0.021)\end{array}$ & 1.337 & $\begin{array}{c}0.037 \\
(0.054)\end{array}$ & 1.515 \\
\hline LEV & $\begin{array}{l}1.147^{* *} \\
(0.154)\end{array}$ & 1.424 & $\begin{array}{l}1.343^{* *} \\
(0.161)\end{array}$ & 1.410 & $\begin{array}{l}1.219 * * \\
(0.325)\end{array}$ & 1.523 & $\begin{array}{l}1.030 * * \\
(0.159)\end{array}$ & 1.411 & $\begin{array}{l}1.275 * * \\
(0.170)\end{array}$ & 1.407 & $\begin{array}{l}0.984 * * \\
(0.316)\end{array}$ & 1.472 \\
\hline ROA & $\begin{array}{l}8.363 * * \\
(0.338)\end{array}$ & 1.075 & $\begin{array}{l}11.319 * * \\
(0.446)\end{array}$ & 1.150 & $\begin{array}{l}6.515^{* *} \\
(0.522)\end{array}$ & 1.064 & $\begin{array}{l}7.168 * * \\
(0.472)\end{array}$ & 1.963 & $\begin{array}{l}12.141 * * \\
(0.640)\end{array}$ & 2.117 & $\begin{array}{l}3.863 * * \\
(0.717)\end{array}$ & 2.059 \\
\hline CAP & $\begin{array}{l}-0.183^{*} \\
(0.092)\end{array}$ & 1.088 & $\begin{array}{l}-0.128 \\
(0.087)\end{array}$ & 1.086 & $\begin{array}{l}-0.309 \\
(0.233)\end{array}$ & 1.178 & $\begin{array}{l}-0.119 \\
(0.096)\end{array}$ & 1.086 & $\begin{array}{l}-0.078 \\
(0.092)\end{array}$ & 1.081 & $\begin{array}{l}-0.233 \\
(0.210)\end{array}$ & 1.175 \\
\hline BIG4 & $\begin{array}{c}0.142 * \\
(0.058)\end{array}$ & 1.193 & & & & & $\begin{array}{l}0.164 * * \\
(0.060)\end{array}$ & 1.191 & & & & \\
\hline IND & Inclu & & Incluc & & Incluc & & Incluc & & Inclu & & Includ & \\
\hline YEAR & Inclu & & Incluc & & Incluc & & Incluc & & Inclu & & Includ & \\
\hline Durbin-Watson & 2.0 & & 1.9 & & 2.19 & & 2.0 & & 2.03 & & 2.20 & \\
\hline F-value & 58.5 & & 65.0 & $7 * *$ & 15.10 & & 50.4 & & 53.43 & & 15.98 & \\
\hline $\mathrm{R}^{2}$ & 0.4 & & 0.6 & & 0.39 & & 0.4 & & 0.56 & & 0.41 & \\
\hline Adjust $\mathrm{R}^{2}$ & 0.4 & & 0.6 & & 0.37 & & 0.4 & & 0.55 & & 0.38 & \\
\hline
\end{tabular}

Notes: ROE is the natural logarithm of the percentage of net income to equity; ETR is the tax expenses for the year divided by earnings before taxes; TAX/ASSET is tax expenses for the year divided by the total assets; SIZE is the natural logarithm of total assets; LEV is the percentage of total debt to total assets; ROA is the percentage of the earnings before taxes to total assets; CAP is the percentage of the net property, plant, and equipment to total assets; BIG4 has the value of one when the firm has BIG4 auditors and zero otherwise; Standard errors are given in parentheses; One and two asterisks indicate statistical significance at the 0.05 level and 0.01 level, respectively.

As previously mentioned, this paper uses a multiple regression analysis technique to analyse data for both full and two sub-samples (BIG4 and non-BIG4 auditors). According to Reference [33], all models in TABLE III do not have any problem of hetero-scedasticity. The problem of autocorrelation also does not exist in all models, as the 
References [34], [35] statistics are between 1.50 and 2.50 [36]. All models further do not have any problem of multicollinearity, since the values of variance inflation factor (VIF) for all variables are less than 10 [37]. The results in TABLE III show that the coefficient for TP (measured by ETR) is statistically and positively significant at the 0.05 level. This result is also consistent with References [3]-[8]. However, the coefficient for TP (measured by TAX/ASSET) is statistically and negatively significant at the 0.05 level. This result is further consistent with References [10]-[15]. It consequently indicates that companies with a higher TP level (measured by ETR) could achieve their higher FP through a reduction in default risk due to a decreasing of agency problems [4], [7]. Nevertheless, it shows that companies with a higher TP level (measured by TAX/ASSET) might have a lower FP because they might use debt financing methods for the TP, accordingly their total liabilities and assets are increased. As a result, the TAX/ASSET rate is decreased.

When dividing the full sample into two sub-groups (BIG4 and non-BIG4 auditors), the results in TABLE III indicate that there is an insignificantly positive relationship between TP (measured by TAX/ASSET) and FP for BIG4 auditors. On the other hand, the relationship between TP (measured by TAX/ASSET) and FP for non-BIG4 auditors is statistically and negatively significant at the 0.05 level, since non-BIG4 auditors are associated with smaller auditing quality, smaller professional skills, and little independence than BIG4 auditors [19]-[23]. The TP (measured by TAX/ASSET), therefore, may be able to increase the FP for BIG4 auditors. Among the control variables, the relationships between SIZE and FP for all models are insignificant. Furthermore, the effects of CAP on the FP for all models are negatively insignificant. However, the effects of LEV and ROA on the FP for the full sample and the separate two sub-samples (BIG4 and non-BIG4 auditors) are statistically and positively significant at the 0.05 level. Finally, the results indicate that the relationship between BIG4 and FP is statistically and positively significant at the 0.05 level.

\section{CONCLUSION}

This paper investigates the impact of TP on the FP of Thai listed companies, which exclude financial sectors, in the SET. The sample size consists of 873 firm-years, during the year 2014-2016. The TP is measured by ETR and TAX/ASSET. The FP is also measured by the ROE. Data analysis is utilised by correlation analysis and multiple regression analysis technique. The paper finds that the TP, which measured by ETR, has a significantly positive effect on the FP, while the TP (measured by TAX/ASSET) has a significantly negative effect on the FP. It consequently indicates that companies with a higher TP level (measured by ETR) could achieve their higher FP through a reduction in default risk due to a decreasing of agency problems. On the other hand, companies with a higher TP level (measured by TAX/ASSET) might have a lower FP because they might use debt financing methods for the TP.

Regarding to control variables, the BIG4 auditors have a significantly positive effect on the FP. The results further indicate that the relationship between TP (measured by TAX/ASSET) and FP is significantly negative for non-BIG4 auditors. The relationship is, thus, weak and insignificant for BIG4 auditors. The results are useful to provide a guideline for listed companies in managing capital and resources more efficiently. Listed companies should, for example, employ BIG4 auditors since the results indicate that the relationship between TP and FP for BIG4 auditors is significantly positive, while for non-BIG4 auditors the relationship is significantly negative.

\section{REFERENCES}

[1] S. D. Dyreng, M. Hanlon, and E. L. Maydew, "Long-run corporate tax avoidance," The Accounting Review, vol. 83, no. 1, pp. 61-82, 2008.

[2] M. Hanlon and S. Heitzman, "A review of tax research," Journal of Accounting and Economics, vol. 50, no. 2-3, pp. 127-178, Dec. 2010.

[3] M. Bita and A. Sabri, "The influence corporate governance on relationship between tax avoidance and firm's value," The Financial Accounting and Auditing Researches, vol. 7, no. 25, pp. 49-64, Jun. 2015.

[4] N. Lestari and R. Wardhani, "The effect of the tax planning to firm value with moderating board diversity," International Journal of Economics and Financial Issues, vol. 5, no. 1S, pp. 10-11, 2015.

[5] T. Eskandarlee and T. M. Sadri, "Impact of management ability on relationship between tax avoidance and firm value in companies listed in Tehran Stock Exchange," Revista QUID, vol. 1, no. 1, pp. 1859-1868, 2017.

[6] W. C. Nugroho and D. Agustia, "Corporate governance, tax avoidance, and firm value," AFEBI Accounting Review, vol. 2, no. 2, pp. 15-29, 2017.

[7] T. Y. H. Tang, "The value implications of tax avoidance across countries," Journal of Accounting, Auditing \& Finance, Nov. 2017.

[8] T. Ying, B. Wright, and W. Huang, "Ownership structure and tax aggressiveness of Chinese listed companies," International Journal of Accounting \& Information Management, vol. 25, no. 3, pp. 313-332, 2017.

[9] J. Tobin, "A general equilibrium approach to monetary theory," Journal of Money, Credit and Banking, vol. 1, no. 1, pp. 15-29, 1969

[10] N. S. Abdul Wahab and K. Holland, "Tax planning, corporate governance and equity value," The British Accounting Review, vol. 44, no. 2, pp. 111-124, Jun. 2012

[11] X. Chen, N. Hu, X. Wang, and X. Tang, "Tax avoidance and firm value: Evidence from China," Nankai Business Review International, vol. 5, no. 1, pp. 25-42, Feb. 2014.

[12] S. L. L. Santana and A. J. Rezende, "Corporate tax avoidance and firm value: Evidence from Brazil,” SSRN Electronic Journal, Jul. 2016.

[13] J. Park, C. Y. Ko, H. Jung, and Y.-S. Lee, "Managerial ability and tax avoidance: Evidence from Korea," Asia-Pacific Journal of Accounting \& Economics, vol. 23, no. 4, pp. 449-477, Oct. 2016.

[14] C. Zhang, K. C. Cheong, and R. Rasiah, "Corporate tax avoidance and performance: Evidence from China's listed companies," Institutions and Economies, vol. 8, no. 3, pp. 61-83, Jul. 2016.

[15] C. S. Yee, N. S. Sapiei, and M. Abdullah, "Tax avoidance, corporate governance and firm value in the digital era," Journal of Accounting and Investment, vol. 19, no. 2, pp. 160-175, Jul. 2018.

[16] D. Olajide, "Tax planning and firms' performance in Nigeria," International Journal of Advanced Research, vol. 5, no. 5, pp. 1950-1956, May 2017.

[17] M. A. Desai and D. Dharmapala, "Corporate tax avoidance and firm value," The Review of Economics and Statistics, vol. 91, no. 3, pp. 537-546, 2009.

[18] T. Pratoomsuwan, "Audit prices and Big 4 fee premiums: further evidence from Thailand," Journal of Accounting in Emerging Economies, vol. 7, no. 1, pp. 2-15, 2017.

[19] L. E. DeAngelo, "Auditor size and audit quality," Journal of Accounting and Economics, vol. 3, no. 3, pp. 183-199, Dec. 1981.

[20] J. R. Francis and E. R. Wilson, "Auditor changes: A joint test of theories relating to agency costs and auditor differentiation," The Accounting Review, vol. 63, no. 4, pp. 663-682, 1988.

[21] H. Lee and H. Lee, "Do Big 4 audit firms improve the value relevance of earnings and equity?," Managerial Auditing Journal, vol. 28, no. 7, pp. 628-646, 2013.

[22] Y.-F. Wang and Y.-T. Huang, "How do auditors increase substantially firm value?," International Journal of Economics and 
Finance, vol. 6, no. 10, pp. 76-82, 2014

[23] M. M. Alfraih, "The role of audit quality in firm valuation: Evidence from an emerging capital market with a joint audit requirement," International Journal of Law and Management, vol. 58, no. 5, pp. 575-598, Sep. 2016.

[24] H. Sayyar, R. Basiruddin, S. Z. Abdul Rsid, and M. A. Elhabib, "The impact of audit quality on firm performance: Evidence from Malaysia," Journal of Advanced Review on Scientific Research, vol. 10, no. 1, pp. 1-19, 2015.

[25] T. Tantiyavarong, "A Study of the Determinants of Tax Planning and the Association between Tax Planning and Firm Value: An Empirical Evidence of Thailand," Chulalongkorn University, 2009.

[26] R. Price, F. J. Román, and B. Rountree, "The impact of governance reform on performance and transparency," Journal of Financial Economics, vol. 99, no. 1, pp. 76-96, Jan. 2011.

[27] E. Swinkels, The Effect of Publishing a GRI Sustainability Report on Financial Performance, Tilburg University, 2012.

[28] S. A. Mirza and A. Javed, "Determinants of financial performance of a firm: Case of Pakistani stock market," Journal of Economics and International Finance, vol. 5, no. 2, pp. 43-52, 2013.

[29] S. Thanjunpong, "Good corporate governance effects on performance through mediation of tax planning of listed companies in the Stock Exchange of Thailand," Journal of the Association of Researchers, vol. 20 , no. 2, pp. 105-113, 2015

[30] T. Awirothananon and S. Thanjunpong, "The impact of corporate governance on cost of debt in Thailand," in Proc. Seoul International Conference on Social Sciences and Management, Asia-Pacific Conference on Education, Society and Psychology, 2017, pp. 619-626.

[31] J. F. Hair, W. C. Black, B. J. Babin, and R. E. Anderson, Multivariate Data Analysis, 7th ed. New Jersey: Pearson Education, 2010.

[32] M. L. Berenson, D. M. Levine, and T. C. Krehbiel, Basic Business Statistics: Concept and Application, 12th ed. New Jersey: Pearson Education, 2012.

[33] H. White, "A heteroskedasticity-consistent covariance matrix estimator and a direct test for heteroskedasticity," Econometrica, vol. 48, no. 4, pp. 817-838, 1980.

[34] J. Durbin and G. S. Watson, "Testing for serial correlation in least squares regression: I,” Biometrika, vol. 37, no. 3/4, pp. 409-428, Dec. 1950.

[35] J. Durbin and G. S. Watson, "Testing for serial correlation in leas squares regression. II," Biometrika, vol. 38, no. 1/2, pp. 159-177, Jun. 1951.

[36] D. N. Gujarati, Basic Econometrics, 4th ed. New York: McGraw-Hill, 2004.

[37] W. H. Greene, Econometric Analysis, 8th ed. New York: Pearson, 2018.

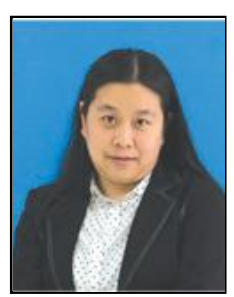

Sathaya Thunjunpong has earned a doctor of business administration in business administration from Naresuan University, Phitsanulok, Thailand. Her major fields are tax planning, corporate governance, and accounting. She is serving as an assistant professor in accounting at Faculty of Business Administration, Maejo University, Sansai, Chiang Mai 50290, Thailand. At the University, she is involved in teaching, research, consultancy, and training. She has also published serval articles in reputed national and international journals.

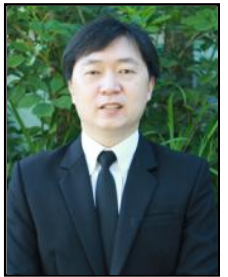

Thatphong Awirothananon has earned a doctor of philosophy from Griffith University, Queensland, Australia. His major interests are financial time series, financial econometrics, and corporate governance. He is serving as an assistant profess in finance at Faculty of Business Administration, Maejo University, Sansai, Chiang Mai 50290, Thailand. He has published serval articles in reputed national and international journals. At the University, he has been involved in teaching, research, consultancy, and training. He is also a member of editorial board of Journal of Management Sciences, Prince of Songkla University, Songkla, Thailand. 